\title{
Cultivating employees' communal relationship and organizational citizenship behavior through authentic leadership: studying the influence of procedural justice
}

This article was published in the following Dove Press journal:

Psychology Research and Behavior Management

\author{
Sadaf Iqbal' \\ Tahir Farid' \\ Jianhong $\mathrm{Ma}{ }^{\prime}$ \\ Qaiser Mehmood ${ }^{2}$ \\ 'Department of Applied Psychology \\ and Behavioral Science, Zhejiang \\ University, Zhejiang, China; \\ ${ }^{2}$ Department of Management, \\ Hamdard University, Islamabad, \\ Pakistan
}

\begin{abstract}
Background: Leaders play vital role in organization to accomplish organizational goals and establish healthy working environment. This study addresses the effect of authentic leadership on employees' communal relationship and organizational citizenship behavior (OCB). In addition, this research also examines how procedural justice augments the effect of authentic leadership on both aforementioned employees' behavioral outcomes.
\end{abstract}

Materials and methods: Using a cross-sectional design, data were collected from 425 employees working in banking sector of Pakistan. It was hypothesized that authentic leadership would positively predict employees' communal relationship and OCB. Furthermore, we also assumed that procedural justice will strengthen the relationship between authentic leadership, both behavioral outcomes, that is, employees' communal relationship and OCB.

Results: Analyses reveal that authentic leadership positively predicts employees' communal relationship and OCB. In addition, procedural justice was found to positively moderate the effect of authentic leadership on employees' communal relationship and OCB.

Conclusion: To our knowledge, this is the first study to investigate the relationships among authentic leadership, procedural justice, communal relationship, and OCBs in the South Asian context. This is the first study to report the moderating role of procedural justice in the relationship between authentic leadership and communal relationship and OCB. The practical implications of study findings and direction for future research are discussed.

Keywords: authentic leadership, communal relationship, organizational citizenship behaviors, procedural justice

\section{Introduction}

Authentic leadership has gained more attention from scholars in the field of positive organizational behaviors due to the upsurge of corporate scandals in organizations, overall management malfeasance, and corrupt management practices. ${ }^{1}$ In addition, the scholars are also addressing the concept of authentic leadership due to its positive effect on employees' workplace outcomes. ${ }^{1,2}$ Although different authors have defined authentic leadership in different ways, in general, it can be defined as the one who is self-aware of his strength and weakness, encourage other participation and not impose his point of view on others, and act in accordance with personal values, feelings and beliefs. ${ }^{1}$ A review of literature reveals the scholarly calls for more empirical research to understand deeply the authentic leader-follower relationship. ${ }^{3-5}$
Correspondence: Jianhong Ma;

Tahir Farid

Department of Applied Psychology and Behavioral Science, Zhejiang University, Zhejiang, China

Tel +86 I39 58159647 ;

+8618626872065

Email jhma@zju.edu.cn;

tahir_khattak@zju.edu.cn 
In addition, positive employee-organization relationships not only help in building organizational reputation but also contribute toward organizational performance and achievement of organizational goals. Similarly, no project can be fulfilled successfully and efficiently if disagreement and misunderstanding exist between employees and their organization. ${ }^{6,7}$ Previous research studies reveal that those employees who have experienced good sustainable relationship with their organization are likely to consider organizational problems as their own and consider finding solutions to these problems as these are their personal problems. ${ }^{8}$ Such employees are more willing to show the positive image of the outside workplace setting of the organization. ${ }^{9}$

Investigating significant relationships that exist between employees and organization, ${ }^{10}$ and, ${ }^{11}$ have identified different types of relationships such as communal relationship and exchange relationships; however, none no study has been conducted on communal relationship in the field of organizational leadership which means "efforts to give benefits to other party with no expectation of returns in future." Communal relationship plays an important role in enabling organization to pay attention to its social responsibilities because it will seek to give benefits to its employees without any direct expectation. ${ }^{11,12} \mathrm{Kim}^{13}$ stated that at workplace, employee perception regarding communal relationship can be considered as the most crucial indicator which affects organization brand and reputation. Understanding the crucial role of employees' communal relationship in the field of organizational leadership, this will be the first attempt which will examine the link between authentic leadership and employees' communal relationship.

Meanwhile, organizational citizenship behavior (OCB) has been one of the most frequently considered studies for scholars in the field of applied psychology, management, and nursing. ${ }^{14,15}$ It is defined as the voluntary individual behavior that is not included in the formal reward system of the organization but boosts the organizational performance as a whole. ${ }^{16}$ At workplace, employees' OCB levels change due to contextual or dispositional variables. ${ }^{17} \mathrm{OCB}$ is highly associated with turnover, in role performance, and leadership attitude and behaviors. ${ }^{18}$ In particular, research related to authentic leadership reveals that authentic leadership behavior plays a significant role in enhancing employees' citizenship behaviors. ${ }^{19,20}$ In the current study, we examined the relationship between authentic leadership and OCB in the context of banking sector in Pakistan. The studies related to the relationship between authentic leadership and OCB are mostly conducted in the western countries. ${ }^{19-21}$ As many researchers call for more empirical research which examines authentic leadership globally, ${ }^{3}$ this study will fill this gap by examining the effect of authentic leadership on OCB in the context of banking sector of Pakistan.

In addition, analyzing the type of relationships, it is therefore important to understand how to enhance the role of authentic leadership in the workplace environment. In this regard, studies suggest the role of moderator in finding the relationship between authentic leadership and job outcomes of followers. ${ }^{3,22}$ The current study investigates the moderating role of procedural justice in finding the relationship between authentic leadership with employees' communal relationship and OCB. Procedural justice is concerned with employees' perception regarding fairness in procedures toward reward allocation. It revealed positive shared opinions of employees regarding transparency of procedures in decision making, judgments of performance and outcomes. If employees perceive fairness in procedures, they are more engaged in extra role behaviors. ${ }^{19}$ In addition, social exchange theory ${ }^{23}$ also plays vital role in affecting employees' attitude and behaviors at workplace, so it is conceivable that if employees perceive fairness in procedures and fair treatment from supervisor they will show more helping behaviors at workplace.

So based on the empirical evidence, the current paper seeks to extend literature on authentic leadership, employees' communal relationships, $\mathrm{OCB}$, and procedural justice by examining the effect of authentic leadership on employees' communal relationship and OCB in Eastern context. The authentic leadership effect has been widely studied in Western contexts. ${ }^{2,21,24-26}$ To address this knowledge gap, we study the impact of authentic leadership in the Pakistani context by identifying the moderating role of procedural justice that should interact with authentic leadership to affect employees' communal relationship and OCB.

\section{Theoretical background and hypothesis development Authentic leadership}

In the field of leadership, the concept of authentic leadership emerged as an interesting area of research. Luthan and Avolio' ${ }^{27}$ idea of authentic leadership provided a base for understanding the concept of authentic leadership and attracted researchers in authentic leadership construct in the area of management. A number of research studies ${ }^{1,21,24,28}$ had refined authentic leadership theory development. The current definition given by Walumbwa et $\mathrm{al}^{1}$ is the most acceptable 
in the field of authentic leadership literature. Authentic leadership can be defined "as the one who is self-aware of his strength and weakness, encourage other participation and not impose his point of view on others, and act in accordance with personal values, feelings and beliefs."

The construct put forward by Walumbwa et $\mathrm{al}^{1}$ is composed of four components of authentic leadership such as self-awareness, relational transparency, balanced processing of information, and internalized moral perspective. First, selfawareness refers to one's awareness about his strength and weakness, desires, and cognitions ${ }^{29}$ and the leaders' inclination to improve social interactions with their followers. ${ }^{30}$ Second, relational transparency refers to openly sharing one's feelings and motives and admitting mistakes. The leaders show their true self to their subordinates which helps in building trust, cooperation, and fosters team work among them. ${ }^{21}$ Moreover, the leader always keeps himself open for inspection. ${ }^{31}$ Third, balanced processing of information refers to quality of being unbiased and gaining accurate information before reaching any collective decision. Fourth, internalized moral perspectives refer to act in accordance with one's moral values and beliefs. ${ }^{29}$

The current study focused on relational influence processes, ${ }^{32}$ which state that authentic leaders have the quality of developing and maintaining strong relationship based on trust, take logical value-based decisions which build subordinates' respect, and encourage mutual team norms. These relational influence processes cultivate deeper engagement and strengthened value-based commitment than conventional exchange mechanism by supporting the rights of decisions in apparent trust-based working atmosphere. Such type of working environment enables leaders to mold desirable behaviors as well as enables followers to recognize their personal motives and drives to develop value-based commitment that is cooperative behavior. We believe that authentic leadership plays pivotal role in fostering communal relationship and OCB at workplace, by making the followers aware about the importance of these relationships.

In addition, social exchange theory is one of the most widespread theoretical paradigms for understanding employees' behaviors at workplace. Social exchange theory stated that "mutual reciprocation is the most basic form of human interactions." ${ }^{23}$ At workplace, this theory speculates interpersonal behaviors (the relationship between supervisor, co-workers, and organization) in terms of exchange of costs and rewards: for instance, if the employees perceive leadership behavior as fair in return, they also show more cooperative behavior. ${ }^{23}$ In addition, studies also indicate OCB in terms of exchange relationship. ${ }^{33}$ So, based on the above discussion, it is conceivable that, authentic leadership plays important role in enhancing employees' OCB at workplace.

\section{Employees' communal relationship}

Clark and Mills ${ }^{34}$ introduced the concept of communal relationship to portray people's concern for other party welfare. In such type, benefits were given to help others with no expectation in return. Researchers who studied communal relationship argue that communal relationship improved the overall organizational reputation. ${ }^{35}$ People who give benefits to others may have a higher probability of support in future and may face less opposition while receiving benefits. ${ }^{11,13,35-38}$ Therefore, scholars have emphasized to build and maintain communal relationships with their management.

\section{Relationship between authentic leadership and employees' communal relationship}

A good leader-follower relationship is vital for long-term organizational success and for employees to feel satisfied at workplace. Similarly, if conflict and confusion exist at work-place between leader and followers, no task can be accomplished and no goal can be achieved. ${ }^{6,7} \mathrm{Kim}^{13}$ suggests that employees' perception of communal relationship is one of the most vital indicators in relation to management reputation. Most of the relationships between the management and employees begin with social exchange relationship. In order to make this relation long term much depends upon leadership efforts to germinate it into communal relationship. Hon and Grunig $^{11}$ stated that nowadays employees want more than just pay for exchange of work.

It is worthwhile to mention that employees' perception of communal relationship with their management can be influenced by transparent, consistent, and truthful leadership behavior. So if employees perceive authentic leadership at workplace, they will ultimately find the existence of communal relationship with that organization. Shen and $\mathrm{Kim}^{39}$ found a positive association between authentic organizational behavior and the quality of organizationemployee relationship. In addition, as mentioned earlier, researchers have suggested more empirical research on identifying various antecedent and consequences of authentic leadership specifically, the factors and conditions that contribute in better understanding of authentic leadersubordinate relationships. ${ }^{3-5}$ The study will fill this gap by examining the relationship in the context of Pakistan.

In addition, the link between authentic leadership and employees' communal relationship can also be explained in light of relational models theory. ${ }^{40,41}$ This theory is composed of four mental schemas (communal sharing, authority ranking, equality matching, and market pricing). Based on the findings 
from different disciplines like psychology, sociology, and anthropology, ${ }^{40,41}$ argued that these four mental schema's (communal sharing, authority ranking, equality matching, and market pricing) exist to some extent almost in all cultures of the world. Communal sharing implies showing care and concern for other members and fulfilling their needs. ${ }^{41}$ So, the communal sharing mental schemas can be highly linked with authentic leadership as the authentic leaders have the ability to enhance social interaction with their followers ${ }^{30}$ and show concern for others by being unbiased and gain accurate information before reaching any final decision. Moreover, the authentic leaders are transparent in showing their true self to subordinates which assists in enhancing cooperation, building trust, and fostering team work among them. ${ }^{21}$ So, based on this theoretical component of communal sharing mental schemas, we argued that if authentic leaders working in banking sectors are perceived as more inclined toward showing care and concern for their followers, which helps in building a communal relationship among team members, in response the employees will show more interest in their work and care for their organization which can ultimately help the organization to develop and flourish. Therefore, it is suggested that authentic leadership is positively associated with employees' communal relationship (Figure 1). Thus we hypothesize that:

\section{Hypothesis I}

Authentic leadership will be positively associated with employees' communal relationship.

\section{$O C B$}

OCB is considered as one of the most essential factors that affect employees' behavior and performance inside the organization. ${ }^{42}$ In recent years, OCB has become a matter of speculation for researchers in different fields like management, psychology, nursing, and environment. ${ }^{15}$ It has been defined by different scholars in different ways. In general it can be defined as employees' positive voluntary behavior that intends to support coworkers and organizational social and psychological environment ${ }^{18}$ and is not formally rewarded. ${ }^{16}$ At workplace, the level of OCB is dynamic and it can change due to different contextual and dispositional variables. ${ }^{17}$

Researchers have analyzed different individuals and organizational factors that affect OCBs. For example, a recent meta-analysis suggests that personality factor positively influence OCB. ${ }^{18}$ In addition, past studies have also suggested that different organizational factors such as organizational justice and perceived organizational support positively affect citizenship behaviors among employees. ${ }^{43,44}$ First, the focus of interest of scholars was psychological antecedent of OCB, such as cognitive, effectual, and contextual factors; ${ }^{33}$ later, scholars found OCB to be related to employees' loyalty and identification with an organization. OCBs also assist organizations' functioning and goal achievement. ${ }^{45-47}$

\section{Relationship between authentic leadership and OCBs}

Leadership is the basic element that molds organizational culture and workplace environment. ${ }^{48}$ Researchers have shown positive association between leadership behaviors and followers' OCB. ${ }^{46}$ In particular, research related to authentic leadership reveals that authentic leadership behavior plays a significant role in enhancing employees' citizenship behaviors. ${ }^{1}$ The current study suggests that authentic leaders openly share information with followers and listen to opinions of other members. ${ }^{21,49,50}$ Such features of leaders create a positive workplace environment where employees understand the significance of OCB and its benefits in achieving organizational goals. ${ }^{51}$

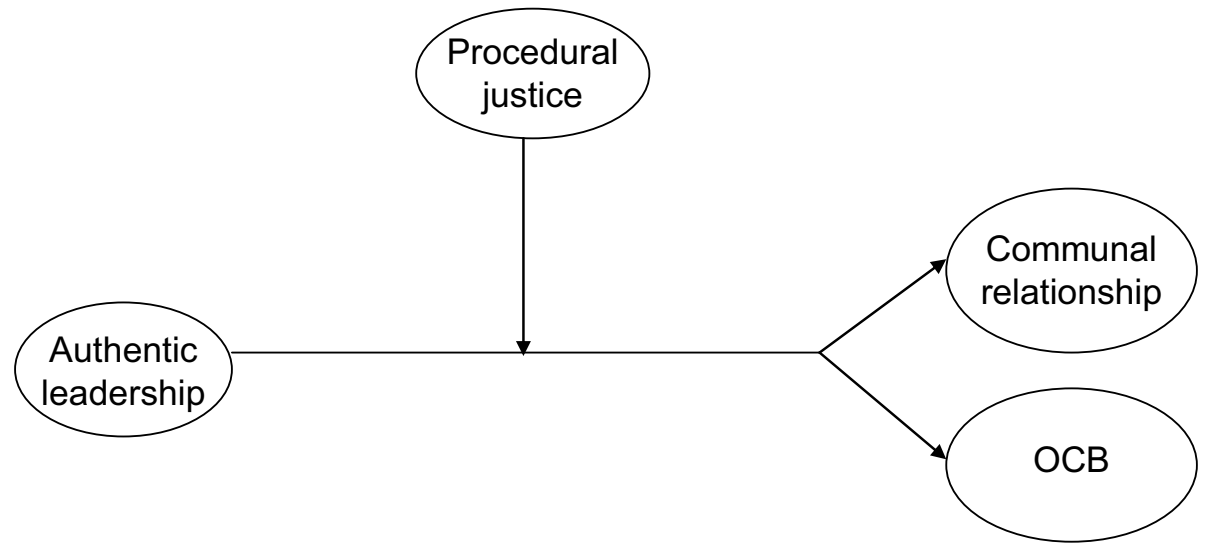

Figure I Hypothetical model of the relationship between authentic leadership (independent variable), procedural justice (moderator), communal relationship, and organizational citizenship behavior (OCB; dependent variables). 
Empirical evidence demonstrates a high correlation between authentic leadership and OCB. For example, a study conducted by Avolio and Gardner ${ }^{28}$ revealed that employees are more engaged in OCB under the supervision of authentic leader who creates open and fair environment. In particular, the goal of the authentic leader is to enhance employees' citizenship behaviors by making them more aware about the significance and benefits of OCB. Studies also revealed a positive and significant role of authentic leadership in predicting self-related OCB. ${ }^{1,25,52,53} \mathrm{So}$, based on the current literature, it is conceivable that when employees of private banking sector perceive leaders' behavior as authentic, they are more likely to exceed their formal duties by exhibiting cooperative behavior to their colleagues and supervisors (Figure 1). Therefore, we propose that:

\section{Hypothesis 2}

Authentic leadership will be positively associated with employees' OCBs.

\section{Moderating role of procedural justice}

Procedural justice refers to the fairness in the process or method toward decision-making. ${ }^{54,55}$ Thibaut and Walker ${ }^{56}$ while introducing the concept of procedural justice stated that people are at least as interested in determining the procedures toward decision-making as they are interested in the outcomes themselves. Procedural justice indicates leaders' fairness and integrity in managing routine activities at work settings. ${ }^{57}$ When it comes to showing justice in keeping transparency in work processes and methods, authentic leaders can be considered as characterized by high level of moral identity and determined by internalized moral perspectives, ${ }^{58}$ and they are further appreciated to keep consistent with their action, words, and beliefs. So these positive traits of authentic leaders indicate a positive inclination toward following procedural justice at workplace. Following fair procedures at workplace creates a sense of being valued and trustworthiness among employees. ${ }^{25}$

Scholars have found that employees' perception about justice plays a vital role in shaping their attitude and behavior at workplace..$^{59,60}$ Procedural justice has been recommended to be linked with leader-follower relationships.$^{61}$ In addition, empirical evidence reveals that authentic leadership plays an important role in enhancing employees' OCB and changing employees' perception about leader fairness at workplace. ${ }^{62}$ Past studies also reveals that procedural justice has profound effects on various job-related outcomes ${ }^{63}$ due to their importance to employees' social belonging and self-admiration. ${ }^{64}$
In addition, it has been found that three important factors of authentic leadership support procedural justice perception such as 1) the degree to which the procedure is moral and ethical, 2) applied regularly among all members, and 3) offer equal opportunity for all group members to speak and affect the outcomes. Moreover, earlier researchers have suggested the role of moderator in finding the relationship between authentic leadership and job outcomes of the followers. ${ }^{3,22}$ Taking into account the authentic leadership dimensions and the above-mentioned authors' suggestions, it is conceivable that procedural justice at workplace positively influences the relationship between authentic leadership behaviors, OCB, and communal relationship when it is rated high (Figure 1). Therefore, we hypothesize the following:

\section{Hypothesis 3}

Procedural justice will positively moderate the relationship between authentic leadership and employees' communal relationship such that the relationship will be stronger when procedural justice is high.

\section{Hypothesis 4}

Procedural justice will positively moderate the relationship between authentic leadership and OCB such that the relationship will be stronger when procedural justice is high.

\section{Materials and methods Sample and procedures}

The current study used a cross-sectional design to collect data from 425 employees working in different private banking sector organizations in the capital city, Islamabad of Pakistan. The researchers visited different banks to highlight the importance of the study and encouraged employees to participate. A formal permission was obtained from every bank manager before conducting data collection procedure. A set of self-administered questionnaires was distributed, among all the potential respondents. In addition, the researchers assured the confidentiality of response to respondents.

By using convenient sampling method, we distributed 500 questionnaires but received 425 complete questions, representing a response rate of $85 \%$. The majority of the respondents (230: 54\%) held a master degree, majority of the respondents (57\%) were aged $21-30$ years, while $32 \%$ were of the age between 31 and 40 years, and the remaining $11 \%$ were aged $41-50$ years. Most of the respondents $(73 \%)$ were male, while $27 \%$ were female. Fifty-five percent of the respondents had 1-5 years of work experience. The majority of the respondents $(77 \%)$ were working as staff member, 
while $(23 \%)$ were working as a manager. The data were analyzed in SPSS program.

\section{Measures}

All the scales were measured by using 5-point Likert scales ranging from strongly disagree to strongly agree.

\section{Authentic leadership}

Authentic leadership scale developed by Walumbwa et $\mathrm{al}^{1}$ was adopted for the study. The scale is composed of 16 items, including "My manager seeks feedback to improve interactions with others," "My manager admits mistakes when they are made," and "My manager demonstrates beliefs that are consistent with actions." Cronbach alpha of the scale was 0.879 .

\section{Communal relationship}

Employees' communal relationship was measured with a 14-item scale developed by Clark et al. ${ }^{65}$ Example items include "When making a decision, I take other people's needs and feelings into account," "I believe people should go out of their way to be helpful." Cronbach alpha of the scale was 0.895 .

\section{$\mathrm{OCB}$}

OCB scale developed by Lee and Allen ${ }^{66}$ was adopted for the study. The scale comprises eight items. Examples include "I willingly give my time to help other staff members who have work-related problems" and "I show genuine concern and courtesy toward staff member, even under the most difficult business or personal situations." Cronbach alpha of the scale was 0.893 .

\section{Procedural justice}

Procedural justice was measured using a scale developed by Niehoff and Moorman, ${ }^{67}$ comprising six items. Examples include "My manager made job decisions in an unbiased manner," "My manager makes sure that all employee concerns are heard before job decisions are made." Cronbach alpha reliability of the scale was 0.756 .

\section{Ethics statement}

This study was carried out in accordance with the recommendations of the guidelines of the ethics commission of the Zhejiang University and obtained written informed consent from all participants. All of them gave written informed consent in accordance with the Declaration of Helsinki. The study was approved formally by the ethics commission of Zhejiang University; ethical approval was not required in Pakistan for this study.

\section{Results \\ Descriptive statistics}

In descriptive statistics, means, standard deviations, and correlations of all the examined variables are presented in Table 1. Authentic leadership was found to be positively correlated with OCB $(r=0.323, P<0.01)$ and communal relationship ( $r=0.538, P<0.01$ ), in the expected (positive) direction. Moreover, procedural justice was found to be positively correlated with OCB $(r=0.132, P<0.01)$ and communal relationship $(r=0.187, P<0.01)$. Altogether these results present preliminary evidence to support our main hypotheses.

\section{Confirmatory factor analysis (CFA)}

To test the construct validity, a set of CFAs were performed in SPSS AMOS. ${ }^{21}$ We first conducted baseline model (model 1) that was composed of all main variables such as authentic leadership, procedural justice, $\mathrm{OCB}$, and communal relationship to calculate the model fit indices (shown in Table 2) and compared with other alternative models. The results reveal a good model fit for the baseline model ( chisquare/degree of freedom $[\mathrm{CMIN} / \mathrm{DF}]=2.152$, comparative fit index $[\mathrm{CFI}]=0.948$, Tucker- Lewis Index $[\mathrm{TLI}]=0.94$, root mean square error of approximation [RMSEA] $=0.048$ ) compared to other proposed models in the study. Model 2 was a three-factor model in which authentic leadership and procedural justice were combined in a single factor. Model 3 was a two-factor model in which authentic leadership and procedural justice were combined together and communal

Table I Mean, SD, and correlations of the variables

\begin{tabular}{|c|c|c|c|c|c|c|}
\hline & Mean & SD & I & 2 & 3 & 4 \\
\hline $\begin{array}{l}\text { Authentic } \\
\text { leadership }\end{array}$ & 3.3991 & 0.70214 & 1 & & & \\
\hline $\mathrm{OCB}$ & 3.7476 & 0.83755 & $0.323 * *$ & I & & \\
\hline $\begin{array}{l}\text { Communal } \\
\text { relationship }\end{array}$ & 3.7176 & 0.66031 & $0.530 * *$ & $0.434 * *$ & I & \\
\hline $\begin{array}{l}\text { Procedural } \\
\text { justice }\end{array}$ & 3.7539 & 0.73757 & 0.076 & $0.132 * *$ & $0.187 * *$ & I \\
\hline
\end{tabular}

Notes: $\mathrm{N}=425 ; * * \mathrm{P}<0.01 ; * \mathrm{P}<0.05$.

Table 2 Results of confirmatory factor analysis

\begin{tabular}{|l|l|l|l|l|}
\hline $\begin{array}{l}\text { Measurement } \\
\text { models }\end{array}$ & CMIN/DF & CFI & TLI & RMSEA \\
\hline (MI) 4 FACTOR & 2.152 & 0.948 & 0.941 & 0.048 \\
(M2) 3 FACTOR & 2.216 & 0.944 & 0.938 & 0.049 \\
(M3) 2 FACTOR & 2.683 & 0.923 & 0.914 & 0.058 \\
(M4) I FACTOR & 3.225 & 0.902 & 0.887 & 0.067 \\
\hline
\end{tabular}

Abbreviations: CMIN/DF, chi-square/degree of freedom; CFI, comparative fit index; TLI, Tucker-Lewis Index; RMSEA, root mean square error of approximation 
relationship and OCB were merged into a single factor. Model 4 was a one-factor in which authentic leadership, procedural justice, communal relationship, and OCB were merged into single factor to form a new bigger factor. CFA with maximum likelihood estimation was conducted for all the four models. The factor loading for each factor was found significant and reveals a good convergent validity. The average variance extracted (AVE) of all proposed variables was checked and the square root of every AVE was found to be greater than all the coefficient of the variables. ${ }^{68}$

\section{Regression analysis}

We conducted multiple linear regression in $\mathrm{SPSS}^{22}$ to test hypotheses $1-4$. The results in Table 3 present the effects of the control variables (age and job experience) and independent variable (authentic leadership) on the dependent variables (communal relationship and OCB). The results shown in Table 3 reveal that authentic leadership is positively and significantly associated with communal relationship $(\beta=0.5546 ; P<0.001)$, hence fully supporting Hypothesis 1. Similarly, Hypothesis 2 predicts the positive association between authentic leadership and OCB. Results indicate that authentic leadership has a significant and positive relationship with $\mathrm{OCB}(\beta=0.3934 ; P<0.001)$, hence Hypothesis 2 is also supported.

\section{Moderating hypotheses analysis}

To test the moderating effect of procedural justice on the relationship between the independent variable (authentic leadership) and dependent variables (communal relationship and OCB), we run multiple linear regression analysis. First, we centered both independent and moderating variables; then, we entered the product terms of independent and

Table 3 Results of regression analysis

\begin{tabular}{|l|l|l|}
\hline Variable & $\begin{array}{l}\text { Communal } \\
\text { relationship }\end{array}$ & OCB \\
\hline $\begin{array}{l}\text { Control } \\
\text { Age }\end{array}$ & -0.082 & 0.037 \\
Job experience & 0.038 & 0.076 \\
$\begin{array}{l}\text { Main effects } \\
\text { Authentic leadership }\end{array}$ & $0.5546^{* * *}$ & $0.3934^{* * *}$ \\
$\begin{array}{l}\text { Interaction effects } \\
\text { Authentic leadership } \times \text { procedural } \\
\text { justice }\end{array}$ & $0.1676^{* * *}$ & $0.2949^{* * *}$ \\
$\mathrm{R}^{2}$ & 0.280 & 0.104 \\
Adjusted $\mathrm{R}^{2}$ & 0.279 & 0.102 \\
$\mathrm{~F}$ & $164.837^{* * *}$ & $49.315^{* * *}$ \\
\hline
\end{tabular}

Notes: $\mathrm{N}=425 ; * * * \mathrm{p}<0.001$. moderating variables (authentic leadership $\times$ procedural justice). The findings revealed that the interactional term of authentic leadership $\times$ procedural justice was significant with employees' communal relationship $(\beta=0.1676, P<0.001)$; therefore, Hypothesis 3 is fully supported.

Likewise, the interactional term of authentic leadership $\times$ procedural justice was found significant with OCB ( $\beta=0.2949, P<0.001$ ); hence, Hypothesis 4 is also fully supported. This means that procedural justice has moderating effects on the relationships between authentic leadership and employees' sustainable communal relationship, and between authentic leadership and OCB.

To further investigate this interaction, we also applied simple slope analysis. Figure 2 indicates that the relationship between authentic leadership and employees' communal relationship was positive when procedural justice was high; however, at low procedural justice, the relationship remained positive but not significant. Simple slope analysis revealed that at high level of procedural justice, the relationship between authentic leadership and employees communal relationship is positive and significant $(\beta=0.470, P<0.01)$, whereas the association becomes insignificant when procedural justice is low.

Figure 3 indicates that the relationship between authentic leadership and OCB was not significant when procedural justice was high while positive and significant when procedural justice was low. Simple slope analysis showed that at low level of procedural justice, the relationship between authentic leadership and OCB is positive and significant ( $\beta=0.570, P<0.001)$, while it is not significant in case of high level of procedural justice. It means that employees give more importance to authentic leadership in performing extra role behaviors.

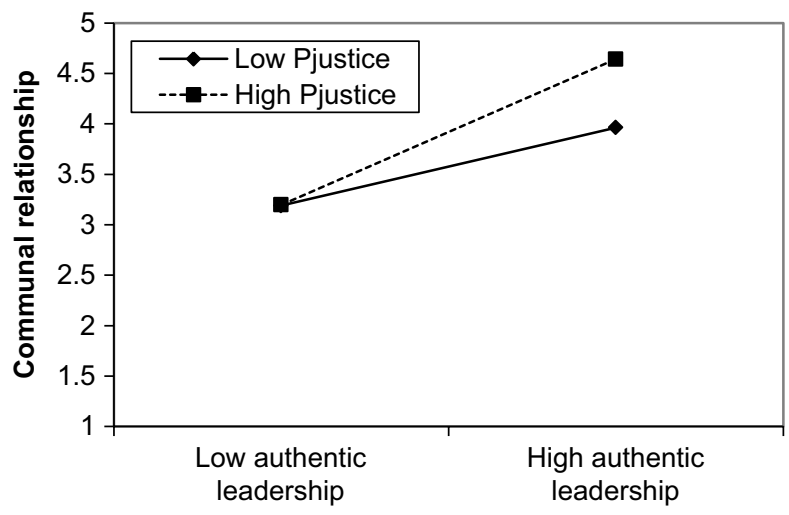

Figure 2 Slope analysis of the moderating effect of high and low procedural justice on the relationship between high and low authentic leadership and communal relationship.

Note: Pjustice refers to procedural justice. 


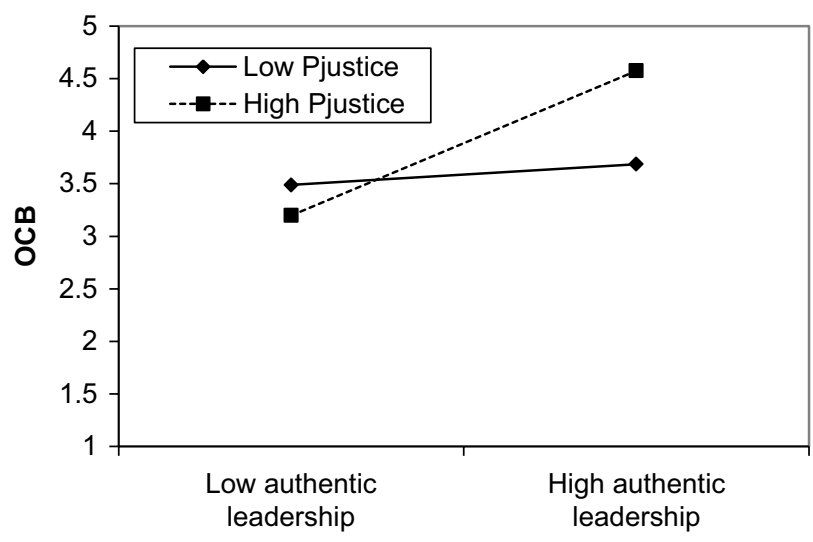

Figure 3 Slope analysis of the moderating effect of high and low procedural justice on the relationship between high and low authentic leadership and organizational citizenship behavior (OCB).

Note: Pjustice refers to procedural justice.

\section{Discussion}

The focus of the current research is twofold. First, to expect the positive effect of authentic leadership on employees' communal relationship and OCB in the context of private banking sectors in Pakistan. Second, to find the moderating effect of procedural justice on the aforementioned relationship. The outcomes of the current study revealed support for all hypothesized relationship in this research. The findings of the research are briefly discussed below.

The results of the current study reveal a positive association between authentic leadership and employees' communal relationship supporting Hypothesis 1. Shen and $\mathrm{Kim}^{39}$ suggest a positive association between authentic organizational behavior and the quality of organization employees' relationship. However, research that has linked authentic leadership behavior with employees' communal relationship was unexplored. We explored this gap and found a positive influence of authentic leadership on employees' communal relationship. In addition, consistent with prior research findings, ${ }^{1,25}$ this study also reveals a positive association between authentic leadership and OCB supporting Hypothesis 2.

In addition, this study also supports the relational influence processes given by Mossholder et al, ${ }^{32}$ which state that authentic leaders have the quality of developing and maintaining strong relationship based on trust, take logical value-based decisions which build subordinates respect, and encourage mutual team norms. Such type of working environment enables leader to mold desirable behaviors as well as enables followers to recognize their personal motives and drives to develop value-based commitment that is cooperative behavior. So our study findings also reveal that authentic leadership has positive effects on employees' communal relationship and OCB.

The findings of the study also support the relation model theory ${ }^{40,41}$ which is composed of four mental schemas which exist to some extent in almost all cultures. Communal sharing components imply showing care and concern for other members and fulfilling their needs. ${ }^{40,41}$ So, our study supports that authentic leadership is found to be positively associated with employees' communal relationship.

As discussed in the preceding discussion, procedural justice indicates leaders' fairness and integrity in managing routine activities at work settings. ${ }^{57}$ In addition, when it comes to showing justice in keeping transparency in work processes and methods, authentic leaders can be considered as characterized by high level of moral identity and determined by internalized moral perspectives; ${ }^{58}$ they are further appreciated to keep consistent with their action, words, and beliefs. So these positive traits of authentic leaders indicate a positive inclination toward following procedural justice at workplace. Researchers suggest that fair procedures at workplace create a sense of being valued and trustworthiness among employees ${ }^{25}$ however, little effort was put into identifying the moderating mechanism between authentic leadership, employees communal relationship, and OCB. This study examined the moderating role of procedural justice on the relationship between authentic leadership, employees' communal relationship, and OCB. The results reveal a positive and significant influence of procedural justice on the relationship between authentic leadership and employees' communal relationship supporting Hypothesis 3. In addition, we also found that procedural justice plays an important role in influencing the relationship between authentic leadership and OCB supporting Hypothesis 4 . These results point to the significant role of procedural justice in facilitating OCB and employees' communal relationship. It means that procedural justice plays important role in influencing the above-mentioned relationship at workplace.

\section{Practical implications, limitation, and future direction}

Leadership plays an important role in nurturing the success of an organization. As such authentic leadership which emphasizes self-awareness, relational transparency, balanced processing of information, and internalized moral perspective should be considered important for long-term organizational success. The results of the current study have revealed that leadership plays an important role in influencing employees' attitudes and behaviors within organizations. Organizations 
need to give specific attention to authentic leadership to enhance employees' communal relationship and OCB. The results of the study are consistent with the studies conducted in Western context. The results found a predictive role of authentic leadership in Pakistani setting, which enlarges its predictive validity. Moreover, this study will assist future researchers in further examining the role of authentic leadership and procedural justice in enhancing employees' communal relationship and OCB. The banking organization can enhance procedural justice by implementing fair and unbiased policies for employees. In addition, the managers must confirm fairness in the workplace by showing fairness in decision-making, using fair procedures to make resource allocations, clearly communicate policies and procedures among all staff members. Due to high pressure on economy, and beginning of multinational banks, the competition in banking has improved. The top management of the banking sector should recognize the significance of authentic leadership style of managers and organize leadership development seminars. Moreover, the authentic leaders of the banking sector should have the ability to understand the needs and problems of their subordinates, build a sense of communal relationship among their team members, and encourage them to exhibit citizenship behaviors to accomplish higher goals.

Although the study results are significant, it also has some limitations. First, the study only focused on private banking sector. It is suggested that the study should be extended to other work settings, to further develop understanding of the relationships among the studied variables. Second, common method bias is also the limitation of the study. Furthermore, studies should be expanded to other departments and groups as well. Thirdly, the current study should be replicated in other countries to increase the findings' generalizability. Finally, future research studies are encouraged to consider other organizational variables, job involvement, employees' intention to stay, and happiness while focusing on authentic leadership.

\section{Acknowledgment}

This work was supported by National Natural Science Foundation of China (grant number 71371166).

\section{Disclosure}

The authors report no conflicts of interest in this work.

\section{References}

1. Walumbwa FO, Avolio BJ, Gardner WL, Wernsing TS, Peterson SJ. Authentic Leadership: Development and Validation of a Theory-Based Measure. J Manage. 2008;34(1):89-126.
2. Walumbwa FO, Luthans F, Avey JB, Oke A. Retracted: Authentically leading groups: The mediating role of collective psychological capital and trust. J Organ Behav. 2011;32(1):4-24.

3. Gardner WL, Cogliser CC, Davis KM, Dickens MP. Authentic leadership: A review of the literature and research agenda. Leadersh $Q$. 2011;22(6):1120-1145.

4. Avolio BJ, Walumbwa FO. Authentic Leadership Theory, Research and Practice: Steps Taken and Steps that Remain. In: Day DV, editor. The Oxford Handbook of Leadership and Organizations. Oxford: Oxford University Press; 2014:331-356.

5. Alilyyani B, Wong CA, Cummings G. Antecedents, mediators, and outcomes of authentic leadership in healthcare: A systematic review. Int J Nurs Stud. 2018;83:34-64.

6. Bajaj R, Sinha S, Tiwari V. Crucial Factors of Human Resource Management for Good Employee Relations: A Case Study. Int J Mining Metallurgy Mech Eng. 2013;1(2):90-92.

7. Tansel A, Gazîoğlu Ş. Management-employee relations, firm size and job satisfaction. Int J Manpower. 2014;35(8):1260-1275.

8. Kim J-N, Rhee Y. Strategic thinking about employee communication behavior (ECB) in public relations: Testing the models of megaphoning and scouting effects in Korea. J Public Relat Res. 2011;23(3):243-268.

9. Men LR, Stacks D. The effects of authentic leadership on strategic internal communication and employee-organization relationships. $J$ Public Relat Res. 2014;26(4):301-324.

10. Clark MS, Mils J. The Difference between Communal and Exchange Relationships: What it is and is Not. Personal Soc Psychol Bullet. 1993;19(6):684-691.

11. Hon LC, Grunig JE. Guidelines for Measuring Relationships in Public Relations. Gainesville, FL: Institute for Public Relations; 1999.

12. Huang C-JF. Exploring types of organization-public relationships and their implications for relationship management in public relations. $J$ Public Relat Res. 2005;17(4):393-426.

13. Kim Y. Strategic communication of corporate social responsibility (CSR): Effects of stated motives and corporate reputation on stakeholder responses. Public Relat Rev. 2014;40(5):838-840.

14. Bowler WM, Halbesleben JRB, Paul JRB. If you're close with the leader, you must be a brownnose: The role of leader-member relationships in follower, leader, and coworker attributions of organizational citizenship behavior motives. Hum Resource Manage Rev. 2010;20(4):309-316.

15. Podsakoff NP, Podsakoff PM, Mackenzie SB, Maynes TD, Spoelma TM. Consequences of unit-level organizational citizenship behaviors: A review and recommendations for future research. J Organ Behav. 2014;35(S1):S87-S119.

16. Organ DW, Podsakoff PM, MacKenzie SB. Organizational Citizenship Behavior: Its Nature, Antecedents. Thousand Oaks, CA: Sage Publications; 2005.

17. Mohammad J, Quoquab F, Rahman NMNA, Idris F. Organisational citizenship behaviour in the Islamic financial sector: does Islamic work ethic make sense? Int J Business Govern Ethics. 2015;10(1):1-27.

18. Podsakoff NP, Whiting SW, Podsakoff PM, Blume BD. Individual- and organizational-level consequences of organizational citizenship behaviors: A meta-analysis. J Appl Psychol. 2009;94(1):122-141.

19. Walumbwa FO, Wu C, Orwa B. Contingent reward transactional leadership, work attitudes, and organizational citizenship behavior: The role of procedural justice climate perceptions and strength. Leadership Quart. 2008;19(3):251-265.

20. Valsania SE, León JAM, Alonso FM, Cantisano GT. Authentic leadership and its effect on employees' organizational citizenship behaviours. Psicothema. 2012;24(4):561-566.

21. Gardner WL, Avolio BJ, Luthans F, May DR, Walumbwa F. "Can you see the real me?" A self-based model of authentic leader and follower development. Leadership Quart. 2005;16(3):343-372.

22. Cooper CD, Scandura TA, Schriesheim CA. Looking forward but learning from our past: Potential challenges to developing authentic leadership theory and authentic leaders. Leadership Quart. 2005;16(3):475-493.

23. Blau PM. Exchange and Power in Social Life. NJ, USA: Transaction Publishers; 1964. 
24. Ilies R, Morgeson FP, Nahrgang JD. Authentic leadership and eudaemonic well-being: Understanding leader-follower outcomes. Leadership Quart. 2005;16(3):373-394.

25. Walumbwa FO, Wang P, Wang H, Schaubroeck J, Avolio BJ. Retracted: Psychological Processes Linking Authentic Leadership to Follower Behaviors. Amsterdam, the Netherlands: Elsevier; 2010.

26. Yammarino FJ, Dionne SD, Schriesheim CA, Dansereau F. Authentic leadership and positive organizational behavior: A meso, multi-level perspective. Leadership Quart. 2008;19(6):693-707.

27. Luthans F, Avolio B. Authentic leadership: a positive development approach. In: Cameron KS, Dutton JE, Quinn RE, editors. Positive Organizational Scholarship. San Francisco: Berrett-Koehler; 2003.

28. Avolio BJ, Gardner WL. Authentic leadership development: Getting to the root of positive forms of leadership. Leadership Quart. 2005;16(3):315-338.

29. Zamahani M, Ghorbani V, Rezaei F. Impact of authentic leadership and psychological capital on followers' trust and performance. Australian J Basic Appl Sci. 2011;5(12):658-667.

30. Mehmood Q, Hamstra MRW, Nawab S, Vriend T. Authentic leadership and followers' in-role and extra-role performance: The mediating role of followers' learning goal orientation. J Occup Organ Psychol. 2016;89(4):877-883.

31. Mazutis D, Slawinski N. Leading Organizational Learning Through Authentic Dialogue. Manag Learn. 2008;39(4):437-456.

32. Mossholder KW, Richardson HA, Settoon RP. Human resource systems and helping in organizations: A relational perspective. Acad Manage Rev. 2011;36(1):33-52.

33. Organ DW. Organizational Citizenship Behavior: The Good Soldier Syndrome. Lexington Books/DC Heath and Com; 1988.

34. Clark MS, Mills J. Interpersonal attraction in exchange and communal relationships. J Pers Soc Psychol. 1979;37(1):12-24.

35. Grunig JE, Huang Y-H. From organizational effectiveness to relationship indicators: Antecedents of relationships, public relations strategies, and relationship outcomes. Public relations as relationship management: A relational approach to the study and practice of public relations. Abingdon-on-Thames, UK: Routledge; 2000:23-53.

36. Huang Y-H. Values of public relations: Effects on organization-public relationships mediating conflict resolution. J Public Relat Res. 2001;13(4):265-301.

37. Clark MS, Mills J, Powell MC. Keeping track of needs in communal and exchange relationships. J Pers Soc Psychol. 1986;51(2):333-338.

38. Mills J, Clark MS. Communications that should lead to perceived exploitation in communal and exchange relationships. J Soc Clin Psychol. 1986;4(2):225-234.

39. Shen H, Kim J-N. The authentic enterprise: Another buzz word, or a true driver of quality relationships? J Public Relat Res. 2012;24(4):371-389.

40. Fiske AP. Structures of Social Life: The Four Elementary Forms of Human Relations: Communal Sharing, Authority Ranking, Equality Matching, Market Pricing. Free Press. NY: Simon \& Schuster; 1991.

41. Haslam N, Fiske AP. Social Expertise: Theory of Mind or Theory of Relationships. Relational Models Theory: A Contemporary Overview. Mahwah, NJ: Erlbaum; 2004:147-163.

42. Rotundo M, Sackett PR. The relative importance of task, citizenship, and counterproductive performance to global ratings of job performance: a policy-capturing approach. J Appl Psychol. 2002;87(1):66-80.

43. Colquitt JA, Conlon DE, Wesson MJ, Porter CO, Ng KY. Justice at the millennium: a meta-analytic review of 25 years of organizational justice research. J Appl Psychol. 2001;86(3):425-445.

44. Riggle RJ, Edmondson DR, Hansen JD. A meta-analysis of the relationship between perceived organizational support and job outcomes: 20 years of research. J Bus Res. 2009;62(10):1027-1030.

45. Podsakoff NP, Whiting SW, Podsakoff PM, Blume BD. Individual-and Organizational-Level Consequences of Organizational Citizenship Behaviors: A Meta-Analysis. Washington, DC, USA: American Psychological Association; 2009.

46. Podsakoff PM, Mackenzie SB, Paine JB, Bachrach DG. Organizational citizenship behaviors: A critical review of the theoretical and empirical literature and suggestions for future research. JManage. 2000;26(3):513-563.
47. Lim BTH, Loosemore M. The effect of inter-organizational justice perceptions on organizational citizenship behaviors in construction projects. Int J Project Manage. 2017;35(2):95-106.

48. Bohn JG. The relationship of perceived leadership behaviors to organizational efficacy. J Leadersh Organ Stud. 2002;9(2):65-79.

49. Avolio BJ, Gardner WL, Walumbwa FO, Luthans F, May DR. Unlocking the mask: a look at the process by which authentic leaders impact follower attitudes and behaviors. Leadership Quart. 2004;15(6):801-823.

50. Avolio BJ, Luthans F. Authentic leadership: A positive development approach. In: Cameron KS, Dutton JE, Quinn RE, editors. Positive Organizational Scholarship. San Francisco, CA: Barrett-Koehler. 2003:241-258.

51. Tyler T, Blader S. Cooperation in Groups: Procedural Justice, Social Identity, and Behavioral Engagement. Abingdon-on-Thames, United Kingdom:Routledge; 2013.

52. Shapira-Lishchinsky O, Tsemach S. Psychological empowerment as a mediator between teachers' perceptions of authentic leadership and their withdrawal and citizenship behaviors. Educ Administrat Quart. 2014;50(4):675-712.

53. Edú Valsania S, Moriano León JA, Molero Alonso F, Topa Cantisano G. Authentic leadership and its effect on employees' organizational citizenship behaviours. Psicothema. 2012;24(4):561-6.

54. Cropanzano R, Greenberg J. Progress in organizational justice: Tunneling through the maze. Int Rev Industrial Organ Psychol. 1997; $12: 317-372$.

55. Greenberg J, Colquitt JA. Handbook of Organizational Justice. Thames, Oxfordshire, UK: Psychology Press; 2013.

56. Thibaut JW, Walker L. Procedural Justice: A Psychological Analysis. Hillsdale, NJ: L. Erlbaum Associates; NY: distributed by the Halsted Press Division of Wiley:1975.

57. Dirks KT, Ferrin DL. Trust in leadership: meta-analytic findings and implications for research and practice. J Appl Psychol. 2002;87(4): 611-628.

58. Zhu W, Avolio BJ, Riggio RE, Sosik JJ. The effect of authentic transformational leadership on follower and group ethics. Leadership Quart. 2011;22(5):801-817.

59. Cole MS, Bernerth JB, Walter F, Holt DT. Organizational justice and individuals' withdrawal: Unlocking the influence of emotional exhaustion. J Manage Stud. 2010;47(3):367-390.

60. Greenberg J. Organizational injustice as an occupational health risk. Acad Manag Ann. 2010;4(1):205-243.

61. Byrne ZS, Editor. How do procedural and interactional justice influence multiple levels of organizational outcomes. Annual Meeting of the Society for Industrial and Organizational Psychology. Atlanta, GA: 1999.

62. Bester J, Stander MW, van Zyl LE, Behavioural empowering. Leadership empowering behaviour, psychological empowerment, organisational citizenship behaviours and turnover intention in a manufacturing division. SA J f Indust Psychol. 2015;41(1):1-14.

63. de Cremer D, Tyler TR. Managing group behavior: The interplay between procedural justice, sense of self, and cooperation. Adv Exp Soc Psychol. 2005;37:151-218.

64. Koper G, van Knippenberg D, Bouhuijs F, Vermunt R, Wilke H. Procedural fairness and self-esteem. Eur J Soc Psychol. 1993;23(3): 313-325.

65. Clark MS, Ouellette R, Powell MC, Milberg S. Recipient's mood, relationship type, and helping. J Pers Soc Psychol. 1987;53(1):94-103.

66. Lee K, Allen NJ. Organizational citizenship behavior and workplace deviance: the role of affect and cognitions. J Appl Psychol. 2002;87(1):131-142.

67. Niehoff BP, Moorman RH. Justice as a mediator of the relationship between methods of monitoring and organizational citizenship behavior. Acad Manage J. 1993;36(3):527-556.

68. Fornell C, Lacker D. Evaluating Structural Equation Modeling for Travel Behavior Research. Transportation research part B, University of Michigan. Chicago, IL: American Marketing Association; 1981:1-25. 
Psychology Research and Behavior Management is an international, peerreviewed, open access journal focusing on the science of psychology and its application in behavior management to develop improved outcomes in the clinical, educational, sports and business arenas. Specific topics covered in the journal include: Neuroscience, memory and decision making; Behavior modification and management; Clinical applications; Business and sports performance management; Social and developmental studies; Animal studies. The manuscript management system is completely online and includes a very quick and fair peer-review system, which is all easy to use. Visit http://www. dovepress.com/testimonials.php to read real quotes from published authors.

Submit your manuscript here: https://www.dovepress.com/psychology-research-and-behavior-management-journal 